\title{
Do students spend enough time learning?
}

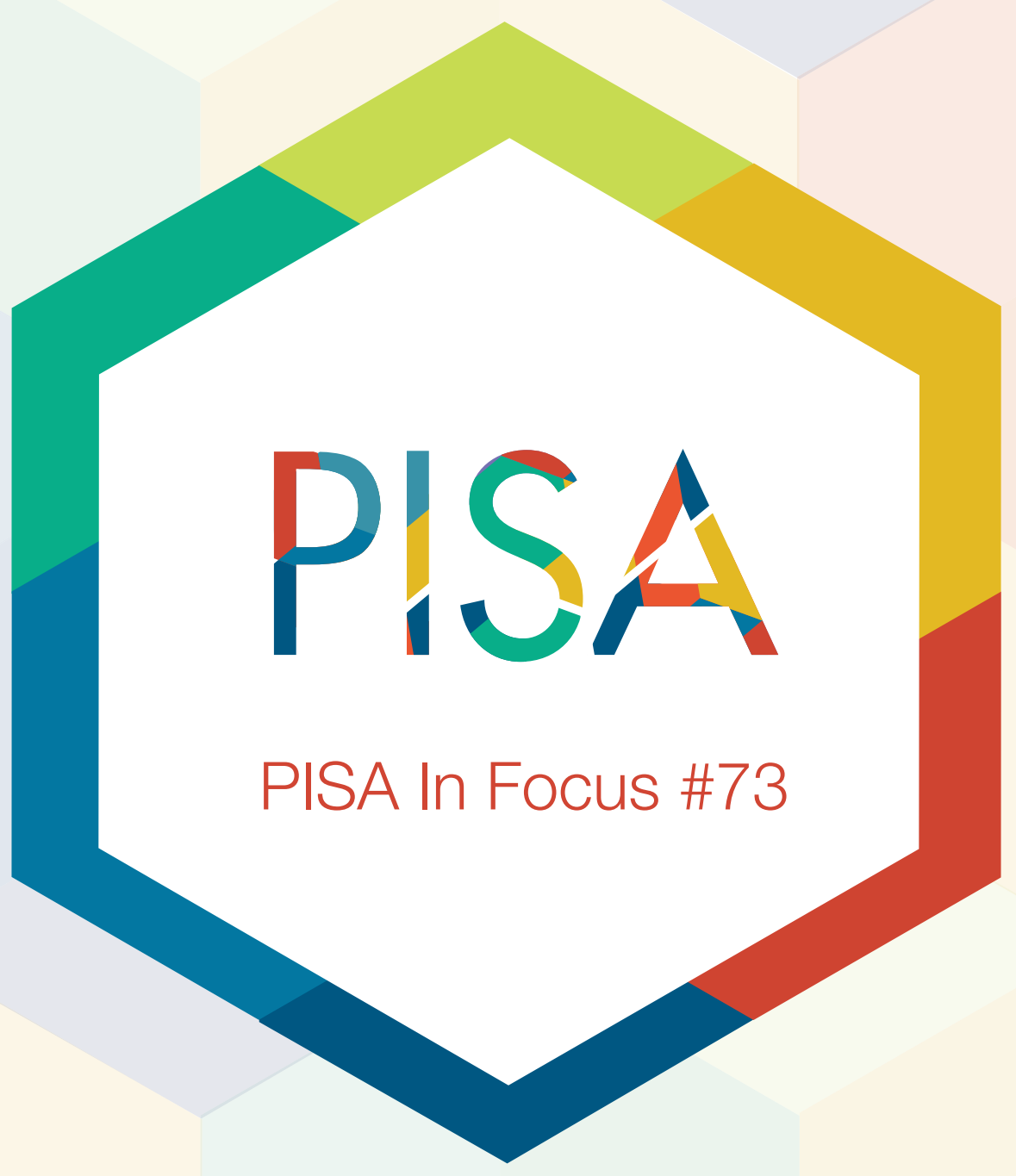




\section{Do students spend enough time learning?}

- In some countries and economies, such as Beijing-Shanghai-Jiangsu-Guangdong (China), Qatar, Thailand, Tunisia and the United Arab Emirates, students spend at least 54 hours per week learning at and outside of school combined, whereas in others, like Finland, Germany, Sweden, Switzerland and Uruguay, students spend less than 40 hours studying.

- Students in Australia, Estonia, Finland, Germany, Japan, the Netherlands, New Zealand, Sweden and Switzerland show the best balance between total learning time and academic performance.

- In school systems where students spend more time in regular science lessons, average science scores are higher; but when students spend more time studying science after school, average science scores are lower.

Time is essential for learning. For example, according to the US Foreign Service Institute, it takes approximately 600 hours for English speakers to acquire general professional proficiency in French, Italian or Spanish, 1100 hours for acquiring such proficiency in Russian, and 200 hours for learning Arabic and Mandarin Chinese. In school, time is needed to give teachers and students opportunities to cover the curriculum, repeat material, provide and receive feedback, and engage in hands-on activities. But increasing learning time alone, such as by making school days or years longer, or shortening lunch breaks, is not enough to improve student outcomes. The question is whether more time leads to fatigue, boredom and burnout, or to productive and effective learning.

PISA 2015 asked 15-year-old students to report the average number of minutes per class period, the total number of class periods per week, and the number of class periods for science, the language of instruction and mathematics they are required to attend in a normal school week. Students were also asked to report the number of hours they typically spend per week, in addition to the required school schedule, learning science, the language of instruction, mathematics, foreign languages and other subjects, including the time they dedicate to homework, additional instruction and private study.

\section{Countries vary considerably in the number of hours students spend studying and in the subjects that are allocated the most instruction time.}

Across OECD countries, students reported spending 44 hours per week learning. This represents approximately $55 \%$ of students' available time, excluding weekends and eight hours of sleep per day. However, in some countries and economies, such as Beijing-Shanghai-Jiangsu-Guangdong (China) (hereafter "B-S-J-G [China]"), Qatar, Thailand, Tunisia and the United Arab Emirates, students spend at least $65 \%$ of their available time learning, whereas in others, notably Finland, Germany, Sweden, Switzerland and Uruguay, students spend less than half of their available time studying.

Most of these differences are explained by the variation in the time students spend studying after school, which includes homework, additional instruction and private study, rather than the time they spend in regular school lessons. For example, students in the United Arab Emirates spend the most time (58 hours) and students in Finland spend the least time (36 hours) learning. But in the United Arab Emirates, students spend about 17 hours more than students in Finland studying after school, yet they spend only 5 hours more learning in regular classes. While policy makers have traditionally focused on how many hours students spend in regular lessons, the time students spend learning and studying after school varies considerably more across students, schools and school systems.

There are also wide differences across school systems in the school time allocated to different subjects. In B-S-J-G (China), Chile, the Russian Federation, Singapore and the United Arab Emirates, at least 18\% of school time is allocated to science, compared to $13 \%$ on average across OECD countries. Among PISA-participating countries and economies, Canada, Chile and Denmark allocate the largest proportion of school time to language-of-instruction classes; Canada, Chile and Peru apportion the largest share of time to mathematics lessons; and Ireland, Korea and Montenegro allocate larger proportions of time to other subjects. 
Learning time, by subject

$\begin{array}{rrrrr}\text { Learning time in regular lessons : } & \text { Science } & \text { Language of instruction } & \text { Mathematics } & \text { Other subjects } \\ \text { After-school study time }{ }^{1}: & \text { Science } & \text { Language of instruction } & \text { Mathematics } & \text { Other subjects }\end{array}$

Learning time as a percentage of available time, excluding eight hours of sleeping time per day and weekends (bottom axis)

Learning time per week (hours) 0

10

20

30

40

50

60

70

Germany

Świtzerland

Uruguay

Sweden

Nètherlands

Czech Republic

New Zealand

Luxembourg

Áústrālia

France

Estonia

Ślovaḱk Repúblic

Norway

Belgium

Lithuania

Latvia

Ünited Kingdom

Bulgaria

Húngary

OÉCD average

Ireland

S̄iovenia

Màcáo (Chinà)

Aústriáa

Canáda

Portúgal

Israel

Croatia

Denmark

Colombia

Póland

Hong Kong (China)

Spāin

Brāzil

Méxic̄ōo

Ũnitēè S̄tātēes

Chininese Táijéi

Greece

Rússia

Costa Rica

täly

Pchílé

Dominican Republic

Montenegro

Turkey

Korea

Singapore

Qátar

Thailand

Tunisia

B-S-J-G (CGhina)
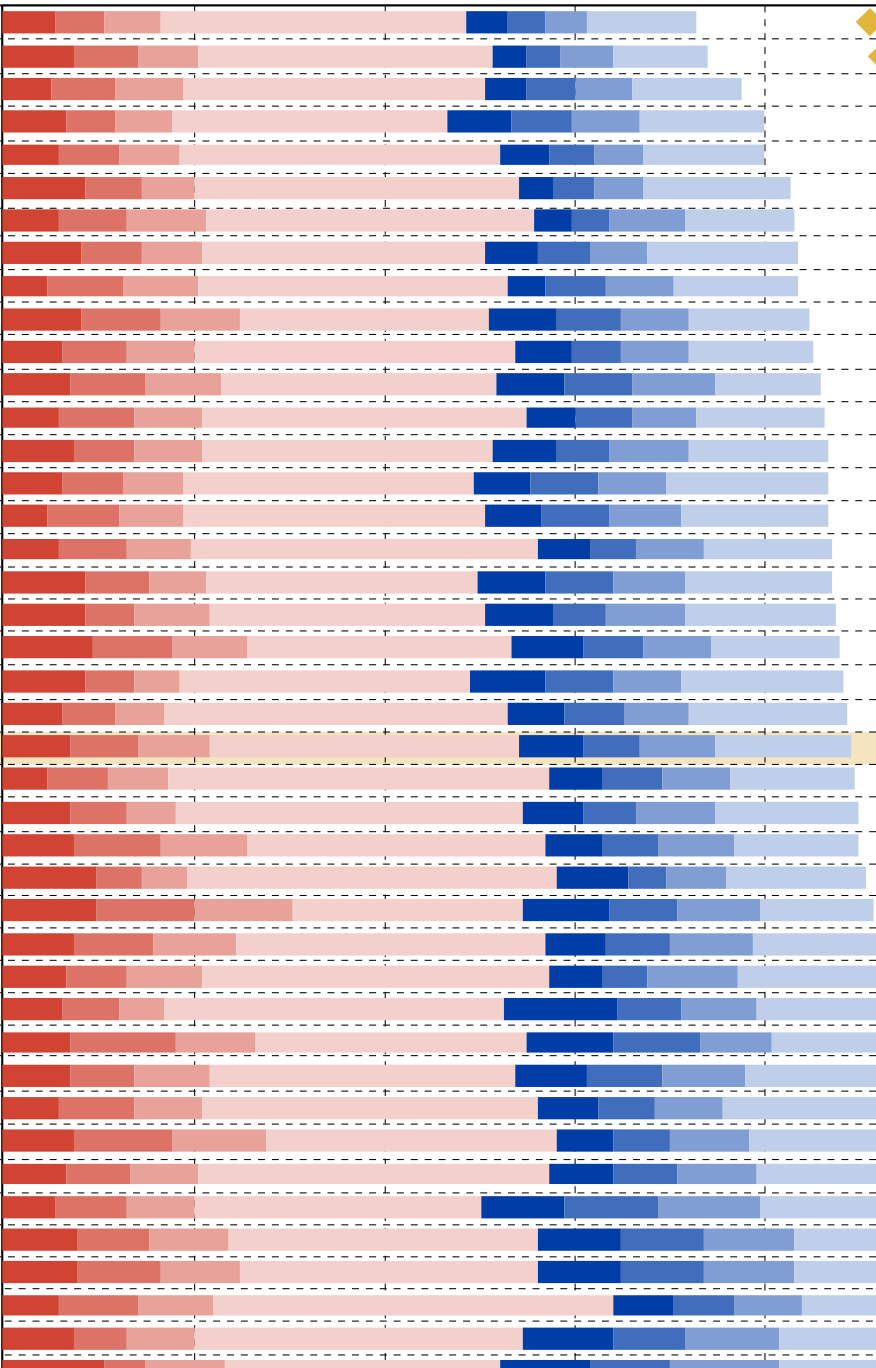

United Aráb Emirates

Learning time as a perce
of available time (\%)
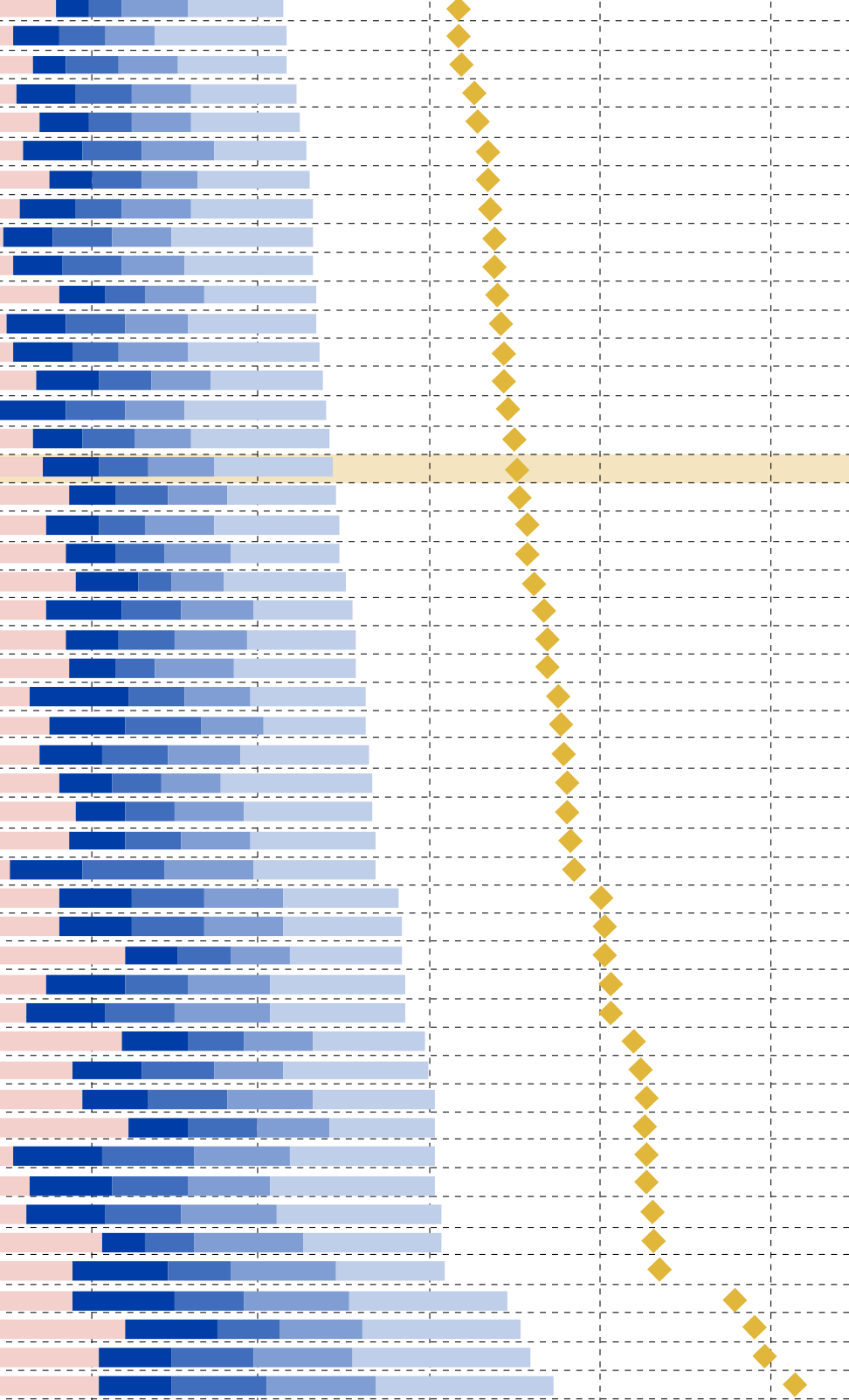

of available time $(\%)$

1. Hours spent learning in addition to the required school schedule, including homework, additional instruction and private study. Countries and economies are ranked in ascending order of the total learning time.

Source: OECD, PISA 2015 Database, Tables II.6.32 and II.6.37. 


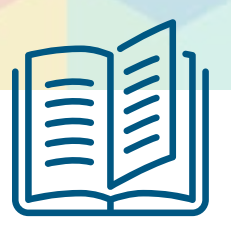

In the debate about how much school time should be allocated to core academic subjects, such as the language of instruction, mathematics and science, and other subjects, like civics, drama, geography, history, music, physical education and technology, some school systems appear to favour the core-subjects approach, rather than the well-rounded approach. For example,

Chilean students spend many hours learning at school - as much as 32 hours per week - and most of this time is allocated to learning core subjects (62\% of school time), such as the language of instruction, mathematics and science, as opposed to other subjects (38\% of school time). There are only four other school systems - Canada (55\%), Singapore (52\%), the United Arab Emirates (52\%) and B-S-J-G (China) (50\%) - where 15-year-old students reported spending at least half of their time at school learning core academic subjects.

\section{Studying more hours does not necessarily lead to better learning outcomes.}

Some countries show a good balance between learning time and academic performance. For instance, in Australia, Estonia, Finland, Germany, Japan, the Netherlands, New Zealand, Sweden and Switzerland, students score at or above the OECD average in science, yet they do not spend long hours learning at school and studying after school, at least in comparison with students in other school systems. By contrast, in other education systems, mainly those in East Asia, including B-S-J-G (China), Hong Kong (China), Korea, Singapore and Chinese Taipei, the typical student scores above the OECD average in science and spends long hours learning.

\section{Learning time and science performance}

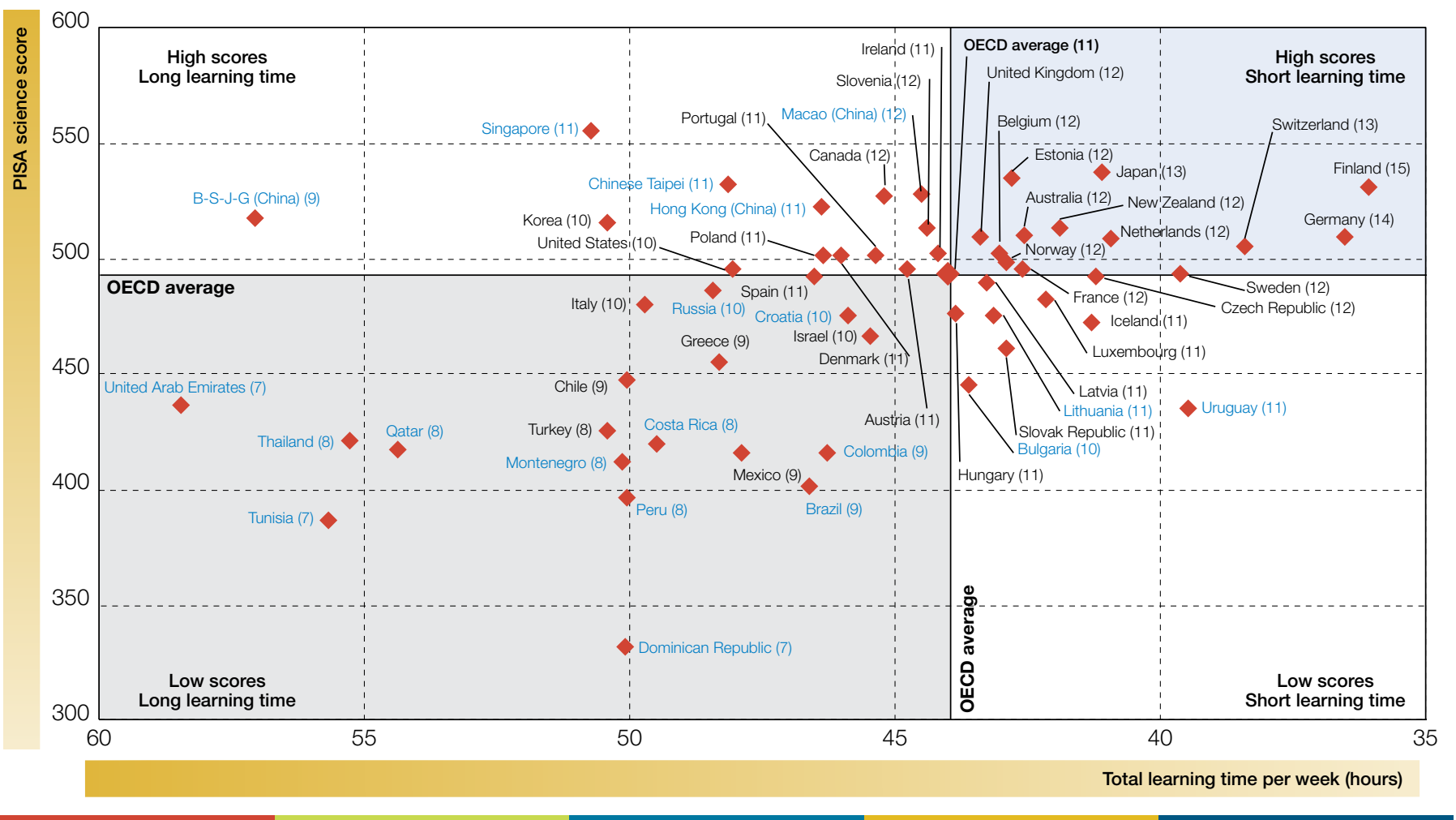

Note: The ratio between the science score and the total learning time per week is shown in parentheses next to the country/economy name. Source: OECD, PISA 2015 Database, Tables I.2.3, II.6.32 and II.6.37.

In other school systems, such as those in Chile, Costa Rica, the Dominican Republic, Montenegro, Peru, Qatar, Thailand, Tunisia, Turkey and the United Arab Emirates, students spend long hours learning, but score significantly below the OECD average in science. In these school systems, the ratio between PISA science scores and total learning time is relatively low. This ratio can be indicative of the efficiency of an education system; but it can also be interpreted in other ways. It can signal differences in learning time across education levels. For example, 15-year-olds in some education systems may be compensating for (or reaping the benefits of) the time spent learning in earlier stages of their education. The ratio might also indicate that, to succeed academically, students in some education systems need to spend more time in "planned" or "deliberate" learning because they have fewer opportunities to learn informally outside of school. After all, students learn mainly at school and in studying for school, but they also learn by interacting with knowledgeable others, such as family members and peers. 
An increase in the average time students spend learning in regular science lessons is associated with an increase in the average science score, at least in those school systems where less time, overall, is spent learning science. Conversely, for every additional hour of average after-school study time, the average science score drops by about 20 points. Based on these results, it could be argued that learning time at school is more effective than studying after school, but also that students in low-performing school systems need to study and participate in after-school learning activities more than students in highperforming systems in order to attain similar learning outcomes.

\section{Learning time in science and adjusted science performance Linear regressions at the system level}

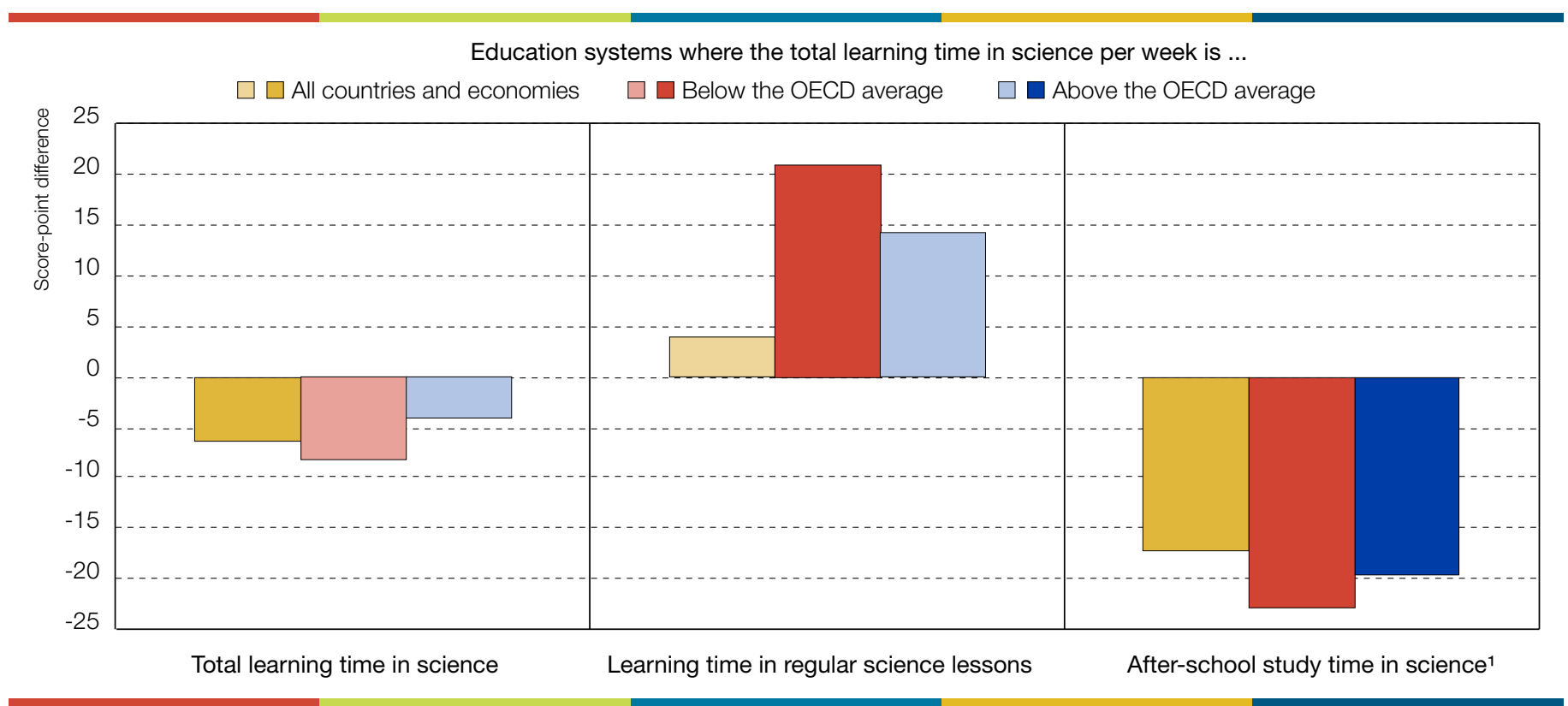

1. Hours spent learning science in addition to the required school schedule, including homework, additional instruction and private study. Notes: Differences that are statistically significant $(p<0.10)$ are marked in a darker tone.

The science score has been adjusted by accounting for socio-economic status (the PISA index of economic, social and cultural status).

Results based on 22 education systems where the total learning time in science is below the OECD average, and 33 education systems where it is above the OECD average.

Source: OECD, PISA 2015 Database, Tables I.6.3a, II.6.32 and II.6.37.

\section{The bottom line}

It is difficult to tell how much time students should spend learning, but it seems clear that many students are spending too much time studying after school - at least more than it seems reasonable if they want to lead a balanced life. Studying and learning after school might not only be inequitable, depending on the quality and availability of after-school learning opportunities, it might also be a lessefficient way of meeting challenging academic standards than learning in regular school lessons. To help students avoid spending a disproportionate amount of time doing homework, receiving additional instruction and studying after school, policy makers, schools, teachers, parents and students should redouble their efforts to make students' learning time at school more productive. 


\section{For more information}

Contact: Alfonso Echazarra (alfonso.echazarra@oecd.org)

See: PISA 2015 Results (Volume II): Policies and Practices for Successful Schools, PISA, OECD Publishing, Paris, http://dx.doi.org/10.1787/9789264267510-en.

Coming next month: How much of a problem is bullying at school?

This paper is published under the responsibility of the Secretary-General of the OECD. The opinions expressed and the arguments employed herein do not necessarily reflect the official views of OECD member countries.

This document and any map included herein are without prejudice to the status of or sovereignty over any territory, to the delimitation of international frontiers and boundaries and to the name of any territory, city or area.

The statistical data for Israel are supplied by and under the responsibility of the relevant Israeli authorities. The use of such data by the OECD is without prejudice to the status of the Golan Heights, East Jerusalem and Israeli settlements in the West Bank under the terms of international law.

This work is available under the Creative Commons Attribution-NonCommercial-ShareAlike 3.0 IGO (CC BY-NC-SA 3.0 IGO). For more detalied information regarding the scope and terms of the licence as well as possible commercial use of this work or the use of PISA data please consult Terms and Conditions at www.oecd.org. 